\title{
FOREST DYNAMICS IN THE EASTERN AMAZON WITH SPECIAL REFERENCE TO SAPOTACEAE SPECIES
}

\author{
Leonardo Pequeno Reis ${ }^{1 *}$, Pamella Carolline Marques dos Reis ${ }^{1}$, Ademir Roberto Ruschel ${ }^{2}$, \\ José Natalino Macedo Silva ${ }^{3}$, João Olegário Pereira de Carvalho ${ }^{3}$, \\ Agostinho Lopes de Souza ${ }^{4}$, Marcio Hofmann Mota Soares ${ }^{2}$, Roberto Koichi Ninokata Miyahara ${ }^{5}$ \\ ${ }^{1 *}$ Universidade Federal de Viçosa, Programa de Pós-Graduação em Ciência Florestal, Viçosa, Minas Gerais, Brasil - \\ leonardo.pequeno@ufv.br; pamellaca.reis@ufv.br \\ ${ }^{2}$ Embrapa Amazônia Oriental, Manejo e Conservação Florestal, Belém, Pará, Brasil - ademir.ruschel@embrapa.br; \\ marcio.soares@embrapa.br \\ ${ }^{3}$ Universidade Federal Rural da Amazônia, Instituto de Ciências Agrárias, Belém, Pará, Brasil - silvanatalino734@gmail.com; \\ olegario.carvalho@gmail.com \\ ${ }^{4}$ Universidade Federal de Viçosa, Departamento de Engenharia Florestal, Viçosa, Minas Gerais, Brasil - alsouza@ufv.br \\ ${ }^{5}$ Universidade Federal Rural da Amazônia, Programa de Pós-graduação em Ciências Florestais, Belém, Pará, Brasil - \\ rknmiyahara@yahoo.com.br
}

Received for publication: 02/04/2014 - Accepted for publication: 22/05/2014

\begin{abstract}
Sapotaceae species are among the most dominant tree species in the Amazon forest and are high valued timbers. This paper aimed to evaluate the effect of Reduced Impact Logging (RIL) over a dense tropical rain forest with special reference to Sapotaceae species, to generate information helping decision making in forest management. In 1997, out of a 1050 ha forest area located in the municipality of Moju, State of Pará, Brazil, 200 ha were selected to be logged applying a logging intensity of $23 \mathrm{~m}^{3} \mathrm{ha}^{-1}$ and RIL techniques. To monitor forest dynamics, 22 permanent sample plots (11 ha sampling area) were established and all trees with DBH $\geq 10 \mathrm{~cm}$ were measured in years 1995 , 1998 and 2010. In the whole observation period, mortality and ingrowth of Sapotaceae species were, respectively, $1.5 \%$ year $^{-1}$ and $1.0 \%$ year $^{-1}$. Trees with full overhead light grew $0.39 \mathrm{~cm}$ year-1 and those completely shaded grew only $0.16 \mathrm{~cm}$ year $^{-1}$. Mortality higher than ingrowth indicates that the population of Sapotaceae species still need a period longer than 13 years to recover equilibrium after RIL, despite showing increased diametric growth rates.

Keywords: Impact after logging; mortality; forest management.
\end{abstract}

\section{Resumo}

Dinâmica de uma floresta no leste da Amazônia com ênfase às espécies de Sapotaceae. As espécies de Sapotaceae estão entre as mais dominantes na floresta amazônica e possuem alto valor comercial. O trabalho objetivou avaliar o efeito da Exploração de Impacto Reduzido (EIR) sobre uma floresta ombrófila densa com ênfase às espécies de Sapotaceae para gerar informações que possam subsidiar decisões a serem tomadas sobre o manejo de florestas nativas. De uma área florestal de 1.050 ha, situada no município de Moju, PA, foram selecionados 200 ha para EIR com intensidade de $23 \mathrm{~m}^{3} \mathrm{ha}^{-}$ ${ }^{1}$ em 1997. O monitoramento florestal foi feito com 22 parcelas permanentes (11 ha), sendo medidas todas as árvores com DAP $\geq 10 \mathrm{~cm}$, nos anos de 1995, 1998 e 2010. No período total (1995 a 2010) a mortalidade das espécies de Sapotaceae foi de $1,5 \%$ ano $^{-1}$ e o ingresso de $1,0 \%$ ano $^{-1}$. As árvores com copas totalmente expostas à luz tiveram o incremento de $0,39 \mathrm{~cm} \mathrm{ano}^{-1}$ e aquelas totalmente cobertas o incremento foi de $0,16 \mathrm{~cm} \mathrm{ano}^{-1}$. A mortalidade maior que o ingresso indica que as espécies de Sapotaceae necessitam de um período maior que 13 anos para recuperar o equilíbrio após a EIR, apesar do aumento no crescimento diamétrico.

Palavras-chave: Impacto pós-colheita; mortalidade; manejo florestal.

\section{INTRODUCTION}

Sapotaceae have great socioeconomic importance in the Brazilian Amazon for including commercial fruit species, like abiu (Pouteria caimito (Ruiz \& Pav.) Radlk. and Pouteria macrophylla (Lam.) Eyma), and many timber species like maçaranduba (Manilkara huberi (Ducke) A. Chev.),

FLORESTA, Curitiba, PR, v. 45, n. 3, p. 567 - 576, jul. / set. 2015.

Reis, L. P. et al.

ISSN eletrônico 1982-4688 / ISSN impresso 0015-3826

DOI: $10.5380 /$ rf.v45i3.35947 
maparajubas (Manilkara bidentata (A. DC.) A. Chev. and Manilkara paraensis (Huber) Standl.), goiabão (Pouteria bilocularis (H.J.P. Winkl.) Baehni and Chrysophyllum lucentifolium Cronquist), curupixás (Micropholis spp), guajarás (Pouteria guianensis Aubl. and Pouteria oppositifolia (Ducke) Baehni) and seringarana (Ecclinusa guianensis Eyma) (REIS et al., 2013).

Survey of commercially exploited forest species, with regard to their recovery, is fundamental to indicate management actions aimed to conservation. In this context, the study of growth, ingrowth and mortality of trees are fundamental instruments to understand the dynamic of exploited species populations. These studies are also base to the development of growth and production models, which make possible the indication of sustainable management methods to produce timber in tropical forests.

Understanding growth of plants in tropical forests helps decision making regarding important silvicultural matters, like optimization of exploitation intensity, silvicultural treatments and periodicity of the cutting cycle, according with the growth rhythm of exploited species (JARDIM et al., 2008; BRAZ et al., 2012). This knowledge is useful as indicator of the forest ecosystem regeneration. In these terms, success of the second cutting is closely connected to restoration of density, which depends on balance between ingrowth and mortality.

Although monitoring of exploited forests in Brazilian Amazon have been running for more than three decades (REIS et al., 2010), a more detailed look over recuperation of managed species is still at an early stage. This work aimed to assess the effect of Reduced Impact Logging (RIL) on a dense tropical rain forest, with emphasis on Sapotaceae species, to generate information possibly assisting decision making on forest management of native species. The hypothesis of this experiment was the following: after logging, Sapotaceae species increase growth and ingrowth, and reduce mortality along time.

\section{MATERIAL AND METHODS}

The study was conducted in a forest area located in the municipality of Moju, State of Pará, with a total area of 1.050 ha, $\left(02^{\circ} 09^{\prime} 46,24^{\prime \prime}\right.$ 'and $02^{\circ} 09^{\prime} 01,22 \mathrm{~S} ; 48^{\circ} 47^{\prime} 33,94^{\prime \prime}$ 'and $\left.48^{\circ} 48^{\prime} 02,95^{\prime \prime} \mathrm{W}\right)$.

Climate of the region is Ami type (hot and humid), according to Köppen classification. Annual rainfall varies from 2.000 to $3.000 \mathrm{~mm}$. Relative humidity is $85 \%$, with average annual temperature of $26^{\circ} \mathrm{C}$. The relief is flat, with formation of dystrophic Yellow Latosol in different textures. Typology of the experimental area is Dense Tropical Rainforest in terra firme (LOPES et al.. 2001).

In 1997, a RIL was applied on an area of 200 ha, cutting 3,3 trees ha ${ }^{-1}$ on average, corresponding to an average volume of $23 \mathrm{~m}^{2} \mathrm{ha}^{-1}$, affecting 25 species, considering the Minimum Cutting Diameter (MCD) of $65 \mathrm{~cm}$. Sapotaceae species included in the cutting where: $M$. huberi with $5,8 \mathrm{~m}^{3} \mathrm{ha}^{-1} ; M$. bidentata; and M. paraenses, which together reached the volume of $0.43 \mathrm{~m}^{3} \mathrm{ha}^{-1}$ (REIS et al., 2013; REIS et al., 2014).

In 1995, before this cutting, 22 permanent stands measuring $50 \mathrm{~m} \times 100 \mathrm{~m}$, were randomly planted and measured, corresponding to 11 ha of sampling area. All trees with Diameter at Breast Height $(\mathrm{DBH}) \geq 10 \mathrm{~cm}$ were registered and measured. Stands were measured again in 1998 and 2010. Local experts in plant species recognition, known in Brazil as "parabotânicos", determined common names of the plants in loco. Botanic samples collected, were lately identified in the herbarium belonging to Embrapa Amazonia Oriental. Botanical identification reports were filed with the following numbers: 292010, 442010, 522010, 652010, 602011, 762011 and 342012.

Mortality rate $\left(\%\right.$ year $\left.^{-1}\right)$ was calculated by the equation proposed by Sheil et al. (1995):

$$
\left.M=\left(1-\left(\left(N_{0}-m\right) / N_{0}\right)^{\frac{1}{t}}\right)\right) \times 100,
$$

where: M: yearly mortality rate; $\mathrm{N}_{0}$ : number of individuals of the initial population; $\mathrm{m}$ : number of dead trees, not considering trees cut in logging; t: time in years.

Casual deaths were considered in the analysis of mortality rate, originated by various factors: pathogens attacks, parasites and herbivores; storms; damage caused by heavy rains or other natural causes (ROSSI et al., 2007a), and anthropic causes too, like damages inflicted during logging and transportation of logs. 
Ingrowths were considered as the number of trees that reached or passed the minimum diameter of $10 \mathrm{~cm}$, in each measurement session, starting from the second one (ROSSI et al., 2007b). The ingrowth rate $\left(\%\right.$ year $\left.^{-1}\right)$ was obtained with the equation proposed by Sheil and May (1996):

$$
I=\left(1-\left(1-i / N_{t}\right)^{\frac{1}{t}}\right) \times 100,
$$

where: I: annual ingrowth; Nt: final number of surviving trees after time t; i: number of ingrowths; $t$ : time in year.

In the analysis of growth, periodic annual increment (PAI) in diameter $\left(\mathrm{cm} \mathrm{year}^{-1}\right)$ was used, calculated with the equation:

$$
P A I=\frac{I P}{t},
$$

where: IP: difference between final and initial diameters; and t: time in years.

In the analysis of growth, crown illumination was divided in three categories: emerging Crown or Completely Exposed to light (CE), Partially Illuminated Crown (CPI) and Completely Shadowed Crown (CCS). Furthermore, for this analysis, the presence of Climbers (With Climbers - CC) or absence of Climbers (Without Cimbers, SC), were considered, because these variables have influence on growth of trees. In the evaluation of these variables, only alive trees, standing and with complete crowns were considered.

Diametric growth rate, ingrowth and mortality analyses were conducted considering the entire community, in other words all the species found in the sampling plot, while each Sapotaceae species was considered separately.

Analysis of variance and test $t$ were performed for independent samples, at $5 \%$ of probability for diameter PAI, with relation to illumination of the crown and infestation of climbers, and Tuckey test was run at 5\% of probability to compare means. To applicate test- $t$ and Anova, Kolmogorov-Smirnov normality test at $5 \%$ of probability was applied. When normality was not verified, the not-parametric Wilcoxon test (independent) at 5\% of probability was applied.

Significance of statistics for ingrowth and mortality between the different periods (1995-1998 and 1998-2010) were verified by the chi-square test $\left(\chi^{2}\right)$ at $5 \%$ of probability.

Data were processed with the Tropical Forests Monitoring Software (MFT) developed by Embrapa Amazônia Oriental. The software Bioestat 5.3 processed statistical analyses.

\section{RESULTS AND DISCUSSIONS}

\section{Ingrowth and mortality}

Reis et al. (2013) and Reis et al. (2014) already describe horizontal structure and diametric distribution of Sapotaceae, and of the entire community. Periods from 1995 to 1998 and from 1998 to 2010 were significantly different in ingrowth $\left(\chi^{2}=145,863 ; \mathrm{Gl}=21 ; \mathrm{p}=<0.0001\right)$ and in mortality $\left(\chi^{2}=\right.$ 172,$431 ; \mathrm{Gl}=21 ; \mathrm{p}=<0.0001$ ), considering the entire community. In the first period (1995 to 1998) mortality $\left(3.3 \%\right.$ year $\left.^{-1}\right)$ was slightly superior to ingrowth $\left(3.1 \%\right.$ year $\left.^{-1}\right)$, mainly due to damage created by exploitation, logging and logs transportation (REIS et al., 2013). In the second period (1998 to 2010), with restoration of density, ingrowth $\left(2.2 \%\right.$ year $\left.^{-1}\right)$ was superior to mortality $\left(1.6 \%\right.$ year $\left.^{-1}\right)$.

Sapotaceae presented higher mortality than the ingrowth rates (negative balance) in the three considered periods (Table 1). From 1995 to 1998 it was $2.8 \%$ year $^{-1}(\mathrm{M})$ and $2.1 \%$ year $^{-1}$ (I); and from 1998 to 2010 there was a severe decline, $1.2 \%$ year $^{-1}(\mathrm{M})$ and $0.8 \%$ year $^{-1}(\mathrm{I})$. In the entire period (1998 to 2010), rates were $1.5 \%$ year $^{-1}(\mathrm{M})$ and $1.0 \%$ year $^{-1}$ (I). Greatest mortality than ingrowth indicates that observation time is still short to detect signs of population restoration with the same rate of the cuttings performed, this means that population of the family is not yet stable.

As it was expected, mortality and ingrowth rates were high soon after logging and became smaller as time went by, with ingrowth rate overcoming mortality rate in the second period of observation. This is because these pioneer species, with short lifetime, die when the canopy starts to close. Several authors (OLIVEIRA et al., 2005; AZEVEDO et al., 2008) already observed this behavior.

FLORESTA, Curitiba, PR, v. 45, n. 3, p. 567 - 576, jul. / set. 2015. 
Table 1. Mortality (M) and Ingrowth (I) of the whole community and of the Sapotaceae species in a tropical rain forest logged using RIL techniques in 1997, in the Municipality of Moju, State of Pará.

Tabela 1. Mortalidade (M) e Ingresso (I) da comunidade total e das espécies de Sapotaceae em uma Floresta Ombrófila Densa submetida à exploração florestal de impacto reduzido em 1997, no município de Moju, estado do Pará.

\begin{tabular}{|c|c|c|c|c|c|c|}
\hline \multirow{3}{*}{ Species } & \multicolumn{2}{|c|}{$1995-1998$} & \multicolumn{2}{|c|}{ 1998-2010 } & \multicolumn{2}{|c|}{$1995-2010$} \\
\hline & $\mathbf{M}$ & $\mathbf{I}$ & $\mathbf{M}$ & $\mathbf{I}$ & $\mathbf{M}$ & $\mathbf{I}$ \\
\hline & \multicolumn{6}{|c|}{$\%$ year $^{-1}$} \\
\hline Chrysophyllum amazonicum T.D. Penn. & 0.0 & 0.0 & 0.0 & 0.0 & 0.0 & 0.0 \\
\hline Chrysophyllum auratum Miq. & 0.0 & 0.0 & 0.0 & 5.8 & 0.0 & 4.6 \\
\hline Chrysophyllum cuneifolium (Rudge) A. DC & 0.0 & 0.0 & 0.0 & 1.6 & 0.0 & 1.2 \\
\hline Chrysophyllum guianense (Eyma) Baehni & 0.0 & 0.0 & 0.0 & 0.0 & 0.0 & 0.0 \\
\hline $\begin{array}{l}\text { Chrysophyllum lucentifolium subsp. pachycarpum Pires \& } \\
\text { T.D. Penn. }\end{array}$ & 0.0 & 0.0 & 0.5 & 0.5 & 0.4 & 0.4 \\
\hline Chrysophyllum manaosense (Aubrév.) T.D. Penn.* & $*$ & $*$ & $*$ & $*$ & $*$ & $*$ \\
\hline Chrysophyllum prieurii A. DC. & 0.0 & 0.0 & 0.0 & 1.0 & 0.0 & 0.8 \\
\hline Chrysophyllum sanguinolentum (Pierre) Baehni & 0.0 & 0.0 & 0.0 & 0.0 & 0.0 & 0.0 \\
\hline Chrysophyllum sp1 & 0.0 & 0.0 & 0.0 & 0.8 & 0.0 & 0.6 \\
\hline Chrysophyllum sparsiflorum Klotzsch ex Miq. & 0.0 & 0.0 & 0.0 & 9.0 & 0.0 & 7.2 \\
\hline Diploon cuspidatum (Hoehne) Cronquist & 0.0 & 0.0 & 0.0 & 0.0 & 0.0 & 0.0 \\
\hline Diploon sp & 0.0 & 0.0 & 0.0 & 0.0 & 0.0 & 0.0 \\
\hline Ecclinusa guianensis Eyma & 0.0 & 0.0 & 0.0 & 0.9 & 0.0 & 0.7 \\
\hline Manilkara bidentata (A. DC.) A. Chev. & 0.0 & 0.0 & 0.0 & 0.0 & 0.0 & 0.0 \\
\hline Manilkara huberi (Ducke) A. Chev.) & 3.4 & 2.3 & 0.5 & 0.3 & 0.9 & 0.5 \\
\hline Manilkara paraensis (Huber) Standl. & 4.1 & 0.0 & 2.9 & 2.9 & 3.1 & 2.3 \\
\hline Micropholis acutangula (Ducke) Eyma & 3.3 & 6.1 & 2.7 & 0.0 & 2.4 & 0.9 \\
\hline Micropholis egensis (A. DC.) Pierre & 0.0 & 0.0 & 0.0 & 0.0 & 0.0 & 0.0 \\
\hline Micropholis guyanensis (A. DC.) Pierre & 0.0 & 4.5 & 0.0 & 0.9 & 0.0 & 1.7 \\
\hline Micropholis venulosa (Mart. \& Eichler) Pierre & 0.0 & 1.8 & 0.5 & 1.0 & 0.4 & 1.2 \\
\hline Pouteria ambelaniifolia (Sandwith) T.D. Penn.* & $*$ & $*$ & $*$ & $*$ & $*$ & $*$ \\
\hline Pouteria anomala (Pires) T.D. Penn. & 0.0 & 0.0 & 0.0 & 0.0 & 0.0 & 0.0 \\
\hline Pouteria bilocularis (H.J.P. Winkl.) Baehni & 0.0 & 0.0 & 0.0 & 0.0 & 0.0 & 0.0 \\
\hline Pouteria brachyandra (Aubrév. \& Pellegr.) T.D. Penn. & 0.0 & 0.0 & 0.0 & 0.0 & 0.0 & 0.0 \\
\hline Pouteria caimito (Ruiz \& Pav.) Radlk. & 0.0 & 3.7 & 0.0 & 2.1 & 0.0 & 2.4 \\
\hline Pouteria cladantha Sandwith & 0.0 & 3.0 & 0.0 & 0.0 & 0.0 & 0.6 \\
\hline Pouteria decorticans T.D. Penn. & 0.0 & 5.1 & 0.0 & 0.6 & 0.0 & 1.6 \\
\hline Pouteria eugeniifolia (Pierre) Baehni & 0.0 & 4.1 & 0.0 & 2.7 & 0.0 & 3.0 \\
\hline Pouteria gongrijpii Eyma & 0.0 & 0.0 & 0.0 & 3.8 & 0.0 & 3.0 \\
\hline Pouteria guianensis Aubl. & 0.0 & 1.9 & 0.0 & 0.8 & 0.0 & 1.1 \\
\hline Pouteria laurifolia (Gomes) Radlk. & 13.1 & 1.2 & 5.8 & 0.0 & 7.2 & 0.0 \\
\hline Pouteria macrocarpa (Mart.) D. Dietr. & 13.8 & 5.6 & 0.0 & 0.0 & 3.1 & 1.2 \\
\hline Pouteria macrophylla (Lam.) Eyma & 0.3 & 1.6 & 0.4 & 0.9 & 0.4 & 1.1 \\
\hline Pouteria minutiflora (Britton) Sandwith & 0.0 & 0.0 & 0.0 & 0.0 & 0.0 & 0.0 \\
\hline Pouteria opposita (Ducke) T.D. Penn.** & $* *$ & $* *$ & 0.0 & 0.0 & $* *$ & $* *$ \\
\hline Pouteria oppositifolia (Ducke) Baehni & 0.0 & 3.7 & 0.0 & 1.2 & 0.0 & 1.7 \\
\hline Pouteria reticulata (Engl.) Eyma & 0.0 & 0.0 & 0.0 & 0.0 & 0.0 & 0.0 \\
\hline Pouteria robusta (Mart. \& Eichler) Eyma & 0.0 & 0.0 & 0.6 & 0.6 & 0.5 & 0.5 \\
\hline Pouteria singularis T.D. Penn. & 0.0 & 0.0 & 0.0 & 0.0 & 0.0 & 0.0 \\
\hline Pouteria sp1 & 0.0 & 0.0 & 0.0 & 0.0 & 0.0 & 0.0 \\
\hline Pouteria spp & 4.9 & 1.9 & 6.6 & 0.0 & 5.8 & 0.0 \\
\hline Pouteria virescens Baehni & 0.0 & 2.7 & 0.7 & 0.5 & 0.5 & 0.9 \\
\hline Indeterminadas botanicamente & 17.7 & 3.3 & 10.8 & 1.0 & 12.5 & 1.7 \\
\hline Total Sapotaceae & 2.8 & 2.1 & 1.2 & 0.8 & 1.5 & 1.0 \\
\hline Total comunidade & 3.3 & 3.1 & 1.6 & 2.2 & 1.9 & 2.4 \\
\hline
\end{tabular}

*: Species recruited in 2010; **: Species recruited in 1998. 
Mortality rate was greater in diameter classes $15,35,85$ and $105 \mathrm{~cm}$, in the period from 1995 to 1998 (Figure 1), considering the whole community. Mortality was caused mainly by damage from logging, which represented alone $58.7 \%$ of total mortality. Comparing the first period to the second (1998 to 2010), mortality rate decreased, demonstrating decline of the dynamics, probably caused by the canopy's closure, despite high rates in 75 and $115 \mathrm{~cm}$ classes, due to natural causes.
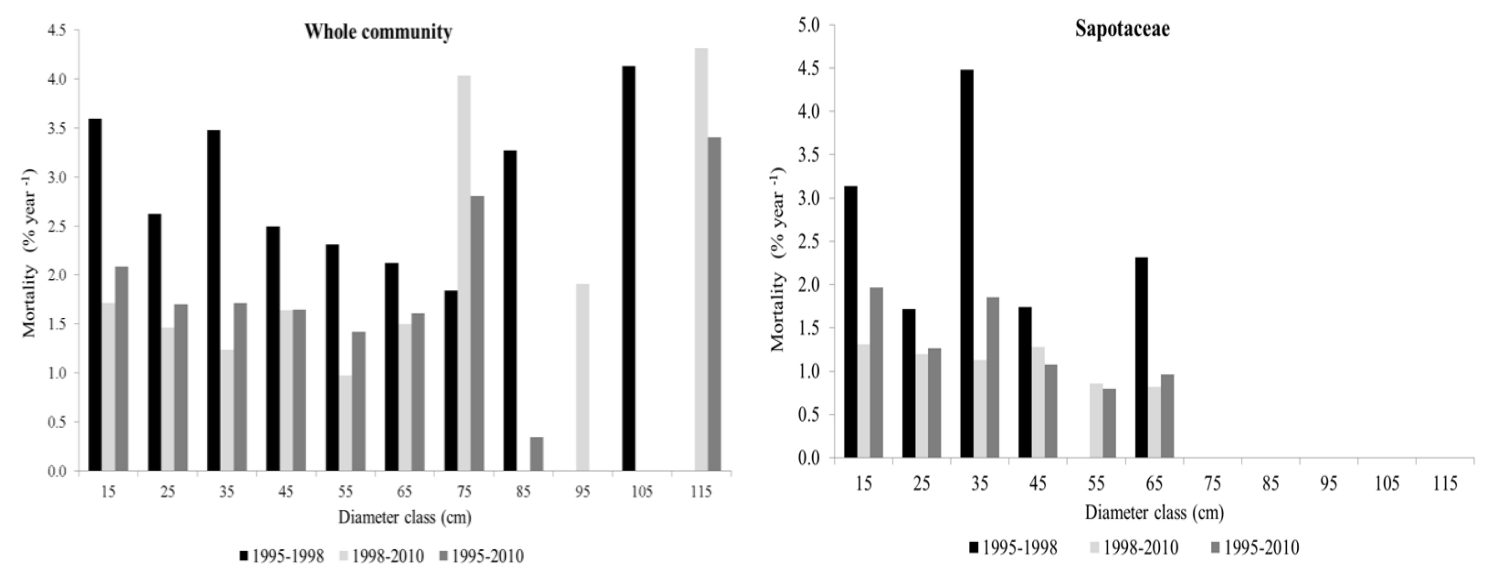

Figure 1. Mortality rate of the whole community (A) and of the Sapotaceae species (B) in different periods and by diameter class in a 11 ha sample of a tropical rain forest selectively logged in the Municipality of Moju, State of Pará.

Figura 1. Taxa de mortalidade de toda a comunidade (A) e de Sapotaceae (B) em diferentes períodos e por classe de diâmetro em uma amostra de 11 ha em uma floresta explorada seletivamente, no município de Moju, estado do Pará.

Diameter classes of Sapoteceae trees that presented greatest mortality rates in the first period (1995 to 1998) were 15, 35 and $65 \mathrm{~cm}$ (Figure 1). This rate diminished in the second period, as happened to the whole community, where classes with highest mortality were 15 and $35 \mathrm{~cm}$. The main mortality cause in the first period was logging, that directly damaged trees. In classes 15,35 and $65 \mathrm{~cm}$, logging damages were responsible respectively for $64.1 \%, 50 \%$ and $54.5 \%$ of the total losses of Sapotaceae trees.

Considering all the Sapotaceae species, in the whole period, 17 presented positive balance between ingrowth and mortality, five negative and 16 had ingrowth equal to mortality, being static for 14 species and dynamic for two. Groups of species formed by Pouteria spp and Botanically Undetermined species, presented greater mortality due to inclusion of trees with uncertain identification in the two groups.

Sapotaceae species with negative balance between ingrowth and mortality (1995 to 2010) were P. laurifolia, M. paraensis, P. macrocarpa, M. acutangula and M. huberi. Among the cited species, only M. acutangula from 1995 to 1998, M. paraensis and P. macrocarpa from 1998 to 2010 (Table 1) presented positive balance or at least ingrowth equal to mortality (dynamic equilibrium).

Mortality of P. laurifolia in the period from 1995 to 1998 was mainly caused by damage from logging operations (64.3\% of mortality). Mortality of M. paraensis and M. acutangula was $100 \%$ caused by logging. M. huberi presented $42.9 \%$ of mortality caused by logging consequences. P. macrocarpa had $100 \%$ of mortality due to natural causes. Out of the five species with highest density in 2010 (Reis et al., 2013), only M. huberi showed negative balance. P. virescens had negative balance from 1998 to 2010. M. guyanensis had $4.5 \%$ of ingrowth and showed no mortality from 1995 to 1998.

RIL caused different reactions concerning mortality and ingrowth, with positive balance considering the whole community, and negative when considering only Sapotaceae species (Table 1). Despite only five species presented negative balance, these are the dominant species of the family in the area, and were damaged by logging, besides the low ingrowth in species with positive balance and in species that continued with the same stock. Thus, RIL must consider recuperation (silivicultural treatments) in the cutting cycle, for species that continue with negative balance between ingrowth and mortality, to equilibrate the family in the area.

FLORESTA, Curitiba, PR, v. 45, n. 3, p. 567 - 576, jul. / set. 2015. 


\section{Growth}

The periodic annual diameter increment of the whole community was $0.29 \mathrm{~cm}_{\text {year }}{ }^{-1}$ in the period from 1995 to 2010 (Table 2). Comparison between growth rates in tropical forests is hard, because it depends on various factors, like state of conservation (exploited or natural forest) and time passed from the last logging, intensity of the cuttings, vegetal composition, site and others. For example, Reis et al. (2010) found increments of $0.25 \mathrm{~cm}_{\text {year }}{ }^{-1}, 26$ years after logging. Vidal et al. (2002), three years after logging, found an increment of $0.63 \mathrm{~cm}^{\text {year }}{ }^{-1}$ with application of reduced impact techniques, and of $0.37 \mathrm{~cm}$ year ${ }^{-1}$ with conventional logging.

Table 2. Periodic annual increment in diameter $\left(\mathrm{PAI}-\mathrm{cm}_{\mathrm{year}}{ }^{-1}\right)$, standard deviation $(\mathrm{sd} \pm)$ and number of sampled trees of the Sapotaceae species and for the whole tree community in a 11 ha sample of a tropical rain forest selectively logged in the Municipality of Moju, State of Pará. N: number of trees.

Tabela 2. Incremento periódico anual em diâmetro (IPAd $-\mathrm{cm}^{\mathrm{ano}}{ }^{-1}$ ), desvio padrão (sd \pm ) e número de árvores amostradas das espécies de Sapotaceae e para o total da comunidade de árvores em uma amostra de 11 ha de Floresta Ombrófila Densa, explorada seletivamente, no município de Moju, estado do Pará. n: número de árvores.

\begin{tabular}{|c|c|c|c|c|c|c|c|}
\hline \multirow{2}{*}{\multicolumn{2}{|c|}{ Species }} & \multicolumn{2}{|c|}{$1995-1998$} & \multicolumn{2}{|c|}{ 1998-2010 } & \multicolumn{2}{|c|}{ 1995-2010 } \\
\hline & & PAI & $\mathbf{n}$ & PAI & $\mathbf{N}$ & PAI & $\mathbf{n}$ \\
\hline Chrysophyllum amazonicum & & $0.16 \pm 0.03$ & 3 & $0.03 \pm 0.04$ & 3 & $0.03 \pm 0.04$ & 3 \\
\hline Chrysophyllum auratum & & 0.19 & 1 & 0.03 & 1 & 0.06 & 1 \\
\hline Chrysophyllum cuneifolium & & $0.26 \pm 0.10$ & 4 & $0.15 \pm 0.15$ & 5 & $0.14 \pm 0.09$ & 5 \\
\hline Chrysophyllum guianense & & 1.01 & 1 & 0.79 & 1 & 0.83 & 1 \\
\hline $\begin{array}{l}\text { Chrysophyllum lucentifolium } \\
\text { pachycarpum }\end{array}$ & subsp. & $0.39 \pm 0.23$ & 14 & $0.34 \pm 0.25$ & 15 & $0.31 \pm 0.22$ & 16 \\
\hline Chrysophyllum manaosense* & & $*$ & $*$ & $*$ & $*$ & $*$ & $*$ \\
\hline Chrysophyllum prieurii & & $0.48 \pm 0.28$ & 15 & $0.40 \pm 0.29$ & 16 & $0.40 \pm 0.22$ & 16 \\
\hline Chrysophyllum sanguinolentum & & $0.24 \pm 0.21$ & 4 & $0.20 \pm 0.26$ & 3 & $0.22 \pm 0.25$ & 3 \\
\hline Chrysophyllum sp1 & & $0.35 \pm 0.19$ & 9 & $0.25 \pm 0.19$ & 9 & $0.26 \pm 0.18$ & 9 \\
\hline Chrysophyllum sparsiflorum & & 0.06 & 1 & 0.03 & 1 & 0.04 & 1 \\
\hline Diploon cuspidatum & & 0.25 & 1 & 0.19 & 1 & 0.20 & 1 \\
\hline Diploon sp & & 0.51 & 1 & 0.37 & 1 & 0.40 & 1 \\
\hline Ecclinusa guianensis & & $0.43 \pm 0.14$ & 8 & $0.40 \pm 0.17$ & 9 & $0.39 \pm 0.17$ & 9 \\
\hline Manilkara bidentata & & $0.31 \pm 0.24$ & 7 & $0.32 \pm 0.26$ & 6 & $0.28 \pm 0.20$ & 7 \\
\hline Manilkara huberi & & $0.38 \pm 0.30$ & 51 & $0.47 \pm 0.33$ & 51 & $0.44 \pm 0.30$ & 50 \\
\hline Manilkara paraenses & & $0.41 \pm 0.20$ & 6 & $0.24 \pm 0.24$ & 4 & $0.24 \pm 0.20$ & 4 \\
\hline Micropholis acutangula & & $0.15 \pm 0.10$ & 8 & $0.07 \pm 0.06$ & 7 & $0.08 \pm 0.06$ & 5 \\
\hline Micropholis egensis & & 0.28 & 1 & 0.30 & 1 & 0.30 & 1 \\
\hline Micropholis guyanensis & & $0.31 \pm 0.24$ & 29 & $0.31 \pm 0.30$ & 36 & $0.31 \pm 0.25$ & 32 \\
\hline Micropholis venulosa & & $0.46 \pm 0.28$ & 15 & $0.37 \pm 0.37$ & 16 & $0.35 \pm 0.34$ & 16 \\
\hline Pouteria ambelaniifolia* & & $*$ & $*$ & $*$ & $*$ & $*$ & $*$ \\
\hline Pouteria anômala & & $0.55 \pm 0.33$ & 9 & $0.50 \pm 0.39$ & 11 & $0.53 \pm 0.33$ & 10 \\
\hline Pouteria bilocularis & & 0.19 & 1 & 0.25 & 1 & 0.24 & 1 \\
\hline Pouteria brachyandra & & $0.11 \pm 0.02$ & 3 & $0.07 \pm 0.02$ & 3 & $0.08 \pm 0.02$ & 3 \\
\hline Pouteria caimito & & $0.31 \pm 0.17$ & 16 & $0.25 \pm 0.26$ & 18 & $0.27 \pm 0.21$ & 16 \\
\hline Pouteria cladanta & & $0.38 \pm 0.37$ & 9 & $0.13 \pm 0.11$ & 11 & $0.19 \pm 0.13$ & 9 \\
\hline Pouteria decorticans & & $0.12 \pm 0.10$ & 10 & $0.10 \pm 0.09$ & 11 & $0.11 \pm 0.08$ & 9 \\
\hline Pouteria eugeniifolia & & $0.27 \pm 0.17$ & 7 & $0.19 \pm 0.23$ & 7 & $0.20 \pm 0.22$ & 7 \\
\hline Pouteria gongrijpii & & $0.09 \pm 0.12$ & 7 & $0.07 \pm 0.10$ & 6 & $0.07 \pm 0.09$ & 7 \\
\hline Pouteria guianensis & & $0.27 \pm 0.19$ & 59 & $0.21 \pm 0.19$ & 64 & $0.22 \pm 0.16$ & 61 \\
\hline Pouteria laurifólia & & $0.17 \pm 0.14$ & 21 & $0.27 \pm 0.22$ & 13 & $0.24 \pm 0.18$ & 13 \\
\hline Pouteria macrocarpa & & $0.09 \pm 0.15$ & 4 & $0.06 \pm 0.07$ & 6 & $0.08 \pm 0.10$ & 4 \\
\hline Pouteria macrophylla & & $0.27 \pm 0.20$ & 82 & $0.17 \pm 0.16$ & 89 & $0.18 \pm 0.14$ & 86 \\
\hline Pouteria minutiflora & & 0.00 & 1 & 0.00 & 1 & 0.00 & 1 \\
\hline
\end{tabular}




\begin{tabular}{lcccccc}
\hline Pouteria opposita** & $* *$ & $* *$ & 0.14 & 1 & $* *$ & $* *$ \\
Pouteria oppositifolia & $0.35 \pm 0.28$ & 19 & $0.30 \pm 0.25$ & 27 & $0.32 \pm 0.25$ & 22 \\
Pouteria reticulata & $0.13 \pm 0.03$ & 3 & $0.02 \pm 0.03$ & 3 & $0.04 \pm 0.03$ & 3 \\
Pouteria robusta & $0.34 \pm 0.26$ & 11 & $0.34 \pm 0.24$ & 13 & $0.30 \pm 0.18$ & 14 \\
Pouteria singularis & $0.23 \pm 0.24$ & 3 & $0.11 \pm 0.06$ & 3 & $0.13 \pm 0.08$ & 3 \\
Pouteria sp1 & 0.22 & 1 & 0.67 & 1 & 0.58 & 1 \\
Pouteria spp & $0.29 \pm 0.27$ & 57 & $0.33 \pm 0.31$ & 29 & $0.33 \pm 0.26$ & 29 \\
Pouteria virescens & $0.23 \pm 0.15$ & 45 & $1.34 \pm 0.2$ & 43 & $0.19 \pm 0.17$ & 47 \\
Botanically undetermined & $0.20 \pm 0.17$ & 25 & $0.10 \pm 0.12$ & 8 & $0.10 \pm 0.12$ & 7 \\
Total Sapotaceae & $0.29 \pm 0.24$ & 572 & $0.27 \pm 0.26$ & 552 & $0.26 \pm 0.23$ & 533 \\
Total Community & $0.36 \pm 0.34$ & 4424 & $0.29 \pm 0.36$ & 4145 & $0.29 \pm 0.32$ & 3870 \\
\hline
\end{tabular}

*: Species recruited in 2010; **: Species recruited in 1998.

In the period from 1995 to 1998 , PAI was higher $\left(0.36 \mathrm{~cm}\right.$ year $\left.^{-1}\right)$ due to the canopy opening caused by logging, naturally decreasing because of the gradual closing of the canopy to $0.29 \mathrm{~cm}^{-\mathrm{ear}^{-1}}$ in the period from 1998 to 2010 (Table 2). Silva et al. (2001) observed that PAI is high in the first years after logging and decreases as times passes, due to the canopy's closing.

Entrance of sun radiation significantly influenced trees growth, detected by the different growth rates in diameter with relation to crown illumination intensity (Table 3), such that trees with directly illuminated crown grew more than the partially shadowed $\left(0.37 \mathrm{~cm} \mathrm{year}^{-1}\right)$, and these also grew more than the completely shadowed by nearby trees $\left(0.16 \mathrm{~cm}\right.$ year $\left.^{-1}\right)$.

Table 3. Periodic annual increment in diameter $\left(\mathrm{PAI}-\mathrm{cm} \mathrm{year}^{-1}\right)$, in the 1995 and 2010 period of the whole tree species community and of five Sapotaceae species in relation to crown illumination in an 11 ha sample of a tropical rain forest selectively logged in the Municipality of Moju, State of Pará. CE: crown emergent; CPI- Crown partially illuminated; and CCS- Crown completely shaded.

Tabela 3. Incremento periódico anual em diâmetro (IPAd $-\mathrm{cm}$ ano $^{-1}$ ) no período de 1995 a 2010 do total da comunidade de árvores e de cinco espécies de Sapotaceae em relação a iluminação da copa em uma amostra de 11 ha de Floresta Ombrófila Densa, no município de Moju, estado do Pará. CE: Copa Emergente; CPI- Copa Parcialmente Iluminada; e CCS- Copa Completamente Sombreada.

\begin{tabular}{|c|c|c|c|c|c|c|c|}
\hline \multirow{3}{*}{ Species } & \multicolumn{6}{|c|}{ 1995-2010 } & \multirow[b]{3}{*}{ Testes } \\
\hline & \multicolumn{6}{|c|}{ Crown illumination } & \\
\hline & $\mathbf{C E}$ & $\mathbf{N}$ & CPI & $\mathbf{N}$ & CCS & $\mathbf{n}$ & \\
\hline Manilkara huberi & & 3 & $0.46 \mathrm{ab}$ & 14 & $0.17 \mathrm{c}$ & 12 & sg; $F=8.654 ; p=0.0016$ \\
\hline Micropholis guyanensis & - & - & 0.46 & 9 & 0.14 & 11 & $\mathrm{sg} ; \mathrm{t}=2.8229 ; \mathrm{p}=0.0117$ \\
\hline Pouteria guianensis & - & - & 0.22 & 20 & 0.23 & 14 & $\mathrm{~ns} ; \mathrm{t}=0.3297 ; \mathrm{p}=0.7437$ \\
\hline Pouteria macrophylla & - & - & 0.18 & 18 & 0.15 & 34 & $\mathrm{~ns} ; \mathrm{t}=0.7127 ; \mathrm{p}=0.4793$ \\
\hline Pouteria virescens & - & - & 0.24 & 5 & 0.15 & 29 & $\mathrm{~ns} ; \mathrm{t}=1.1725 ; \mathrm{p}=0.2496$ \\
\hline Total Sapotaceae & $0.39 \mathrm{a}$ & 7 & $0.33 \mathrm{ab}$ & 135 & $0.16 \mathrm{c}$ & 192 & $\mathrm{sg} ; \mathrm{F}=33.369 ; \mathrm{p}<0.0001$ \\
\hline Total community & $0.49 \mathrm{a}$ & 72 & $0.37 \mathrm{~b}$ & 1045 & $0.16 \mathrm{c}$ & 1350 & $\mathrm{sg} ; \mathrm{F}=165.302 ; \mathrm{p}<0.0001$ \\
\hline
\end{tabular}

t: t-test; F: Anova. Means followed by the same letter in line of each species are not statistically different by the Tuckey test at $5 \%$ of probability.

Clearing of crowns to receive solar radiation is, thus, a silvicultural measure to increase growth. Impact of logging helped growth by opening the canopy and decreasing competition, characterized by the analysis of illumination of crown related to growth.

Sapotaceae presented smaller PAI than the whole community, probably due to the species belonging to the ecological group of shadow tolerant species (Reis et al., 2013), characterized by slow growth rates. Increment in diameter was decreasing as time went by, with $0.29 \mathrm{~cm}$ year ${ }^{-1}$ from 1995 to 1998 and $0.27 \mathrm{~cm}_{\text {year }}{ }^{-1}$ from 1998 to 2010. In the whole period (1995 to 2010), average was $0.26 \mathrm{~cm}$ year $^{-1}$. Despite the family is composed by shadow tolerant species, environments with more illumination gave bigger growth rate (Table 3 ).

Out of the five species with biggest density, two showed significant difference in PAI (1995 to 2010), with relation to crown illumination (Table 3): M. huberi $\left(0.44 \mathrm{~cm} \mathrm{year}^{-1}\right)$ and M. guyanensis $(0.31$ $\mathrm{cm}$ year $\left.^{-1}\right)$. This total growth for M. huberi confirms results registered by Silva et al. (2001) in the

FLORESTA, Curitiba, PR, v. 45, n. 3, p. 567 - 576, jul. / set. 2015.

Reis, L. P. et al.

ISSN eletrônico 1982-4688 / ISSN impresso 0015-3826

DOI: $10.5380 /$ rf.v45i3.35947 
National Forest of Tapajós, PA, of $0.50 \mathrm{~cm} \mathrm{year}^{-1}$ and Vitoria do Jari, AP, of $0.40 \mathrm{~cm}_{\text {year }}{ }^{-1}$. Carvalho et al. (2004) pointed out that $M$. huberi obtained more diameter increment in the logged area than in the natural area, due to more illumination passing through canopy in the first case.

PAI of M. huberi was higher in completely illuminated crown environments $\left(0.62 \mathrm{~cm}^{-1} \mathrm{yr}^{-1}\right)$ and partially illuminated $\left(0.46 \mathrm{~cm}\right.$ year $\left.^{-1}\right)$; with significant difference compared to environments with complete shadowing $\left(0.17 \mathrm{~cm}_{\text {year }}{ }^{-1}\right)$. Costa et al. (2007) in the National Forest of Tapajós also observed this behavior after logging, where plants of the species that received complete illumination grew $0.67 \mathrm{~cm}$ year $^{-1}$ on average, while plants with partial illumination or totally shadowed had smaller growth, respectively of $0.58 \mathrm{~cm}_{\text {year }}{ }^{-1}$ and $0.26 \mathrm{~cm}_{\text {year }}{ }^{-1}$.

M. huberi, just like other shadow tolerant species, responds positively to canopy opening in terms of growth (COSTA et al., 2007), being this an important consideration to support prescriptions of post-logging treatments, especially operations aimed to free crowns. Various authors demonstrated the post-logging treatments efficiency in growth increase and mortality decrease (OLIVEIRA et al., 2005; AZEVEDO et al., 2007; AZEVEDO et al., 2012).

Increment of trees of the whole community, without climbers, was $0.32 \mathrm{~cm}^{-1}$ year $^{-1}, 27 \%$ higher than in trees with climbers (Table 4). Influence of climbers on trees growth is a relatively well proved fact (VIDAL et al., 2002; COSTA et al., 2008). Species of Sapotaceae did not present significant difference in PAI between trees with and without climbers. This was due to the reduced presence of climbers totally covering Sapotaceae trees crowns.

Table 4. Periodic annual increment in diameter (PAI $-\mathrm{cm}$ year $\left.^{-1}\right)$, in the 1995 and 2010 period of the whole tree species community and of five Sapotaceae species in relation to climber infestation in an 11 ha sample of a tropical rain forest selectively logged in the Municipality of Moju, State of Pará. No climber (SC) and with climber (CC).

Tabela 4. Incremento periódico anual em diâmetro (IPAd $-\mathrm{cm}^{\text {ano }}{ }^{-1}$ ) no período de 1995 a 2010 do total da comunidade de árvores e de cinco espécies de Sapotaceae em ao grau de infestação de cipós em uma Floresta Ombrófila Densa, no município de Moju, estado do Pará. Sem Cipó (SC) e Com Cipó (CC).

\begin{tabular}{lccccc}
\hline Species & SC & $\mathbf{n}$ & $\mathbf{C C}$ & $\mathbf{N}$ & Tests \\
\hline Manilkara huberi & 0.51 & 16 & 0.40 & 15 & $\mathrm{~ns} ; \mathrm{t}=0.9219 ; \mathrm{p}=0.3641$ \\
Micropholis guyanensis & 0.38 & 9 & 0.32 & 13 & $\mathrm{~ns} ; \mathrm{t}=0.4912 ; \mathrm{p}=0.6286$ \\
Pouteria guianensis & 0.24 & 13 & 0.22 & 21 & $\mathrm{~ns} ; \mathrm{t}=0.5085 ; \mathrm{p}=0.6146$ \\
Pouteria macrophylla & 0.18 & 26 & 0.17 & 27 & $\mathrm{~ns} ; \mathrm{t}=0.2728 ; \mathrm{p}=0.7861$ \\
Pouteria virescens & 0.21 & 9 & 0.14 & 25 & $\mathrm{~ns} ; \mathrm{w}=126 ; \mathrm{p}=0.6117$ \\
\hline Total Sapotaceae & 0.23 & 143 & 0.21 & 166 & $\mathrm{~ns} ; \mathrm{t}=1.8867 ; \mathrm{p}=0.0615$ \\
Total community & 0.32 & 1238 & 0.25 & 1119 & $\mathrm{sg} ; \mathrm{w}=613.922 .5 ; \mathrm{p}<0.0001$ \\
\hline t: t-test; w: Wilcoxon (independent); sg: significant at 5\% of probability; $\mathrm{ns}$ : not significant at 5\% of probability.
\end{tabular}

Costa et al. (2007) demonstrated that $M$. huberi trees presented bigger growth when without climbers $\left(0.60 \mathrm{~cm}_{\text {year }}{ }^{-1}\right)$ than when climbers were present $\left(0.45 \mathrm{~cm}_{\text {year }}{ }^{-1}\right)$, and indicated that cutting of climbers is a good silvicultural treatment for trees of this species, after logging has taken place. In this work, $M$. huberi did not present statistically significant difference (Table 4) between growth rates of trees without climbers $\left(0.50 \mathrm{~cm}_{\text {year }}{ }^{-1}\right)$ and trees with climbers $\left(0.40 \mathrm{~cm}_{\text {year }}{ }^{-1}\right)$. It is worth to highlight that, before logging, all climbers with diameter bigger than $2 \mathrm{~cm}$ had been cut, which could explain the little influence of these competitors detected when sample plots were evaluated.

\section{CONCLUSIONS}

- Reduced impact logging had influence on ingrowth and mortality of Sapotaceae species. Mortality bigger than ingrowth indicates that Sapotaceae species need more than 13 years to re-establish the original stock.

- RIL accelerated tree species growth, including Sapotaceae, in a short period after logging, indicating that silvicultural treatments can be applied to reduce competition for light in order to continue with accelerated growth rates. Adequate cutting of climbers before logging may reduce damages that caused mortality during RIL, as oriented trees cutting and construction of optimized paths and roads may help to reduce damages caused by logging and transportation of logs. 


\section{ACKNOWLEDGMENTS}

This work received financial support of the Silvicultural Project EMBRAPA/DFID and Good Management Project EMBRAPA/CIFOR /ITTO Projeto PD 57/99 Rev.2 (F), acknowledgment of the authors is granted to these institutions. Authors are also thankful to CAPES and CNPq for granting postgraduation scholarships.

\section{REFERENCES}

AZEVEDO, C. P.; SANQUETTA, C. R.; SILVA, J. N. M.; MACHADO, S. A. Efeito de diferentes níveis de exploração e de tratamentos silviculturais sobre a dinâmica da floresta remanescente. Floresta, Curitiba, v. 38, n. 2, p. 277 - 293, 2008.

AZEVEDO, C. P.; SANQUETTA, C. R.; SILVA, J. N. M.; MACHADO, S. A.; SOUZA, C. R.; OLIVEIRA, M. M. Predição da distribuição diamétrica de uma floresta manejada experimentalmente através de um Sistema de Equações Diferenciais. Acta Amazonica, Manaus, v. 37, n. 4, p. 521 - 532, 2007.

AZEVEDO, C. P.; SILVA, J. N. M.; SOUZA, C. R.; SANQUETTA, C. R. Eficiência de tratamentos silviculturais por anelamento na floresta do Jari, Amapá. Floresta, Curitiba, v. 42, n. 2, p. 315 - 324, 2012.

BRAZ, E. M.; SCHNEIDER, P. R.; MATTOS, P. P.; SELLE, G. L.; THAINES, F.; RIBAS, L. A.; VUADEN, E. Taxa de corte sustentável para manejo das florestas tropicais. Ciência Florestal, Santa Maria, v. 22, n. 1, p. 137 - 145, 2012.

CARVAlHO, J. O. P.; SILVA, J. N. M.; LOPES, J. C. A. Growth rate of a terra firme rain forest in Brazilian Amazonia over an eight-year period in response to logging. Acta Amazonica, Manaus, v. 34, n. 2, p. 209 - 217, 2004.

COSTA, D. H. M.; CARVALHO, J. O. P.; BERG, E. V. D. Crescimento diamétrico de maçaranduba (Manilkara huberi Chevalier) após a colheita da madeira. Amazônia, Belém, v. 3, n. 5, p. 65 - 76, 2007.

COSTA, D. H. M.; SILVA, J. N. M.; CARVALHO, J. O. P. Crescimento de árvores em uma área de terra firme na floresta nacional do tapajós após a colheita de madeira. Revista de Ciências Agrárias, Belém, n. 50, p. $63-76,2008$.

JARDIM, F. C. S.; SENA, J. R. C.; MIRANDA, I. S. Dinâmica e estrutura da vegetação com DAP $\geq 5 \mathrm{~cm}$ em torno de clareiras da exploração florestal seletiva, em Moju Pará. Revista de Ciências Agrárias, Belém, n. 49, p. 41 - 52, 2008.

LOPES, J. C. A.; WHITMORE, T. C.; BROWN, N. D.; JENNING, S. B. Efeito da exploração florestal nas populações de mudas em uma floresta tropical úmida no município de Moju, PA. In:SILVA, J. N. M; CARVALHO, J. O. P.; YARED, J. A. G. (Eds.). A silvicultura na Amazônia Oriental: contribuições do projeto Embrapa/DFID. Belém, 2001. p. 203 - 226.

OliVeIRA, L. C.; COUTO, H. T. Z. do; SILVA, J. N. M.; CARVALHLO, J. O. P. de. Efeito da exploração de madeira e tratamentos silviculturais na composição florística e diversidade de espécies em uma área de 136 ha na Floresta Nacional do Tapajós, Belterra, Pará. Scientia Forestalis, Piracicaba, n. 69, p. $62-76,2005$.

REIS, L. P.; RUSCHEL, A. R.; COELHO, A. A.; LUZ, A. S. da; MARTINS-DA-SILVA, R. C. V. Avaliação do potencial madeireiro na Floresta Nacional do Tapajós após 28 anos da exploração florestal. Pesquisa Florestal Brasileira, Colombo, v. 30, n. 64, p. 265 - 281, 2010.

REIS, L. P.; RUSCHEL, A. R.; SILVA, J. N. M.; REIS, P. C. M.; CARVALHO, J. O. P.; SOARES, M. H. M. Dinâmica da distribuição diamétrica de algumas espécies de Sapotaceae após exploração florestal na Amazônia Oriental. Revista de Ciências Agrárias, Belém, v. 57, p. 234 - 243, 2014.

FLORESTA, Curitiba, PR, v. 45, n. 3, p. 567 - 576, jul. / set. 2015. 
REIS, L. P.; SILVA, J. N. M.; REIS, P. C. M.; CARVALHO, J. O. P.; QUEIROZ, W. T.; RUSCHEL, A. R. Efeito da exploração de impacto reduzido em algumas espécies de Sapotaceae no leste da Amazônia. Floresta, Curitiba, v. 43, n. 3, p. 395 - 406, 2013.

REIS, P. C. M.; REIS, L. P.; RUSCHEL, A. R.; SILVA, J. N. M.; CARVALHO, J. O. P.; QUEIROZ, W. $T$. Effect of timber harvesting on density and basal area of Lecythidaceae species in the eastern Amazon. Floresta, Curitiba, v. 44, n. 2, p. 229 - 238, 2014.

ROSSI, L. M. B.; KOEHLER, H. S.; ARCE, J. E.; SANQUETTA, C. R. Modelagem de recrutamento em florestas. Floresta, Curitiba, v. 37, n. 3, p. 453 - 467, 2007 a.

ROSSI, L. M. B.; KOEHLER, H. S.; SANQUETTA, C. R.; ARCE, J. E. Modelagem de Mortalidade em Florestas Naturais. Floresta, Curitiba, v. 37, n. 2, p. 275 - 291, 2007 b.

SHEIL, D.; BURSLEM, D. F. R. P.; ALDER, D. The interpretation and misinterpretation of mortality rate measures. Journal of Ecology, Oxford, v. 83, n. 2, p. 331 - 333, 1995.

SHEIL, D.; MAY, R. M. Mortality and recruitment rate evaluations in heterogeneous tropical forests. Journal of Ecology, Oxford, v. 84, n. 1, p. 91 - 100, 1996.

SILVA, J. N. M.; SILVA, S. M. A. da; COSTA, D. H. M.; BAIMA, A. M. V.; OLIVEIRA, L. C. de; CARVALHO, J. O. P. de; LOPES, J. C. A. Crescimento, mortalidade e recrutamento em florestas de terra firme da Amazônia Oriental: observações nas regiões do Tapajós e Jarí. In: SILVA, J.N.M.; CARVALHO, J. O. P. de; YARED, J. A. G. (Eds.). A silvicultura na Amazônia Oriental: Contribuições do projeto Embrapa/DFID. Belém, 2001. p. 291 - 308.

VIDAL, E.; VIANA, V. M.; BATISTA, J. L. F. Crescimento de floresta tropical três anos após colheita de madeira com e sem manejo florestal na Amazônia Oriental. Scientia Forestalis, Piracicaba, n. 61, p. $133-143,2002$. 